Du texte à la scène : langages du théâtre

\title{
Doubling as a language of transformation: The case of The Old Wife's Tale
}

\section{Leanore Lieblein}

\section{(C) OpenEdition}

\section{Journals}

\section{Electronic version}

URL: http://journals.openedition.org/shakespeare/476

DOI: $10.4000 /$ shakespeare.476

ISSN: 2271-6424

\section{Publisher}

Société Française Shakespeare

\section{Printed version}

Date of publication: 1 November 1983

Number of pages: 225-246

\section{Electronic reference}

Leanore Lieblein, «Doubling as a language of transformation: The case of The Old Wife's Tale », Actes des congrès de la Société française Shakespeare [Online], 4 | 1983, Online since 01 January 2007,

connection on 02 May 2019. URL : http://journals.openedition.org/shakespeare/476 ; DOI : 10.4000/ shakespeare.476 
SOCIETE FRANÇAISE SHAKESPEARE

Actes du Congrès 1982

\section{DU TEXTE A LA SCENE : Langages du Théâtre}

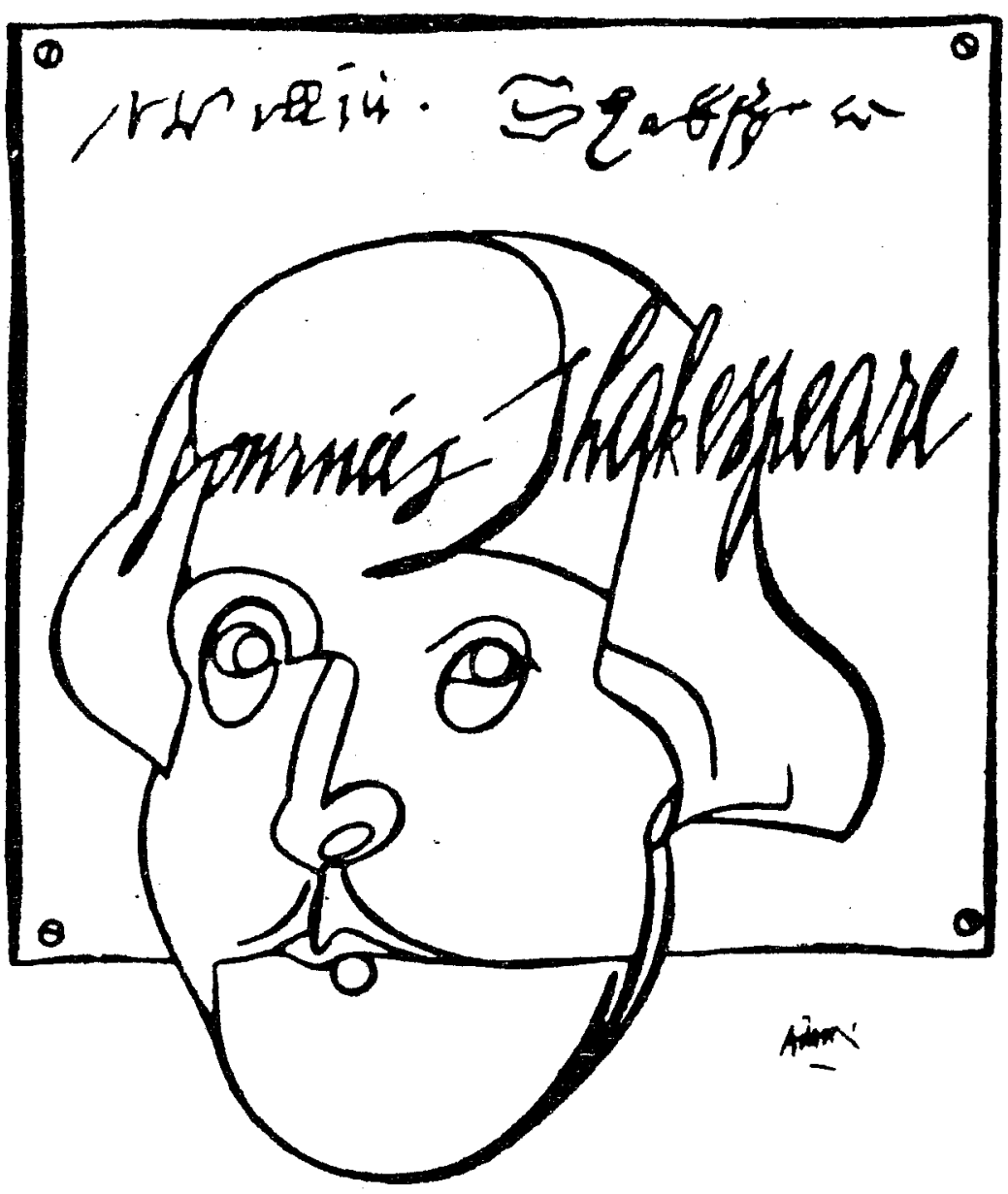

DiRecteur de la publication M.T. Jones - Davies

Publié avec le concours du Centre National de la Recherche Scientifique

JEAN TOUZOT Libraire - Editeur

38 , rue Saint-Sulpice 75278 PARIS CEDEX 061983 
Du Texte à la Scène : Langages du Théâtre.

\section{DOUBLING AS A LANGUAGE OF TRANSFORMATION: THE CASE OF THE OLD WIVES TALE}

Discussions of doubling in Elizabethan plays have ranged from the technical to the fanciful. But from William A. Ringler's careful line counts and tabulations to Stephen Booth's avowed speculations, critics have sought to assess the implications for play and audience of various patterns of doubling. 1

Two basic positions emerge. For some doubling is historically interesting and critically illuminating but theatrically distracting : "What use is it to the theatregoer who will not be able to recognize doubling if it is properly executed and will be annoyed by it if it is carried out too obviously ?» ${ }^{2}$ Such a comment presupposes that doubling, «properly executed,» should not be recognizable. This conflicts with the historical evidence. David Bevington has stressed the versatility of Tudor actors who frequently played on both sides of the psychomachia in good and evil, serious and comic, straight and character roles. Complete changes of character were commonly effected in under thirty lines of dialogue, and some changes occurred in as few as five lines. A change of hat, of beard, of cloak, or of visor would have been sufficient to establish the new character. ${ }^{3}$ In such cases the audience would surely have recognized that an actor had changed his role. It is more likely, as Booth contends, that the doubling of parts is in and of itself a source of theatrical energy for actors who delight in their own skill and audiences who «revel in the theatricality of theater». In fact Booth|argues that «Shakespeare used the doubling of parts in performance adjectivally - to inform, comment on, and, perhaps, augment the events enacted». Thus he suggests that strategic doubling «takes its particular play one step further in its own direction $\gg .^{4}$

Booth's assertion is admittedly speculative. However I would like to illustrate how doubling worked - adjectivally, as he says - in practice in a production of George 
Peele's The Old Wives Tale which I co-directed in $1981^{5}$. To begin with, our situation was not too different from that of an Elizabethan acting company. We too began with a group of a fixed size, and although the possibility of «hirelings» in the form of open auditions for unfilled roles existed, we chose for pedagogical as well as theatrical reasons to make a virtue of necessity.

On the whole, critics of The Old Wives Tale have seen in the successive entrances of unprepared-for characters, some of whose stories are not concluded, the signs of a truncated manuscript, an abridgement, a flawed dramatic structure, a burlesque or parody, or a deliberate attempt to reproduce either the incoherence of an old woman telling a story or the surrealistic qualities of a dream. ${ }^{6 !}$ In order to produce the play on the modern stage, of course, one must stand committed to the belief that whether or not the 1595 quarto, which forms the basis of the text as we presently have it, represents Peele's original and fullest intention, it possesses artistic integrity which can be realized in performance. Unless such «problems» as the fact that Clunch and Antic disappear from the play after little more than a hundred lines never to return can be turned to dramatic advantage, the play must fail on the stage.

Characters disappear, critics have pointed out, because the actors playing them probably doubled in other roles, and although there are a number of ways of unifying the play in performance, I suggest that the possibility for such doubling - the need for it given the probable size of the Queen's Men in the late 1580's and early 1590 's - represents a strength rather than weakness of The Old Wives Tale. In fact the doubling of roles is a means whereby the structural and thematic coherence of the play can be made clear.

Although it has been the subject of much discussion, we do not know under what circumstances or with how many actors The Old Wives Tale was presented. The Queen's Men, to whom it is ascribed on the title page, 
numbered twelve when they were founded in 1583 , and possibly as few as nine in 1588, although the list that survives may be incomplete. We know that more than once the company divided in two for travelling purposes, and that in 1590-1591, one of the sub-companies combined with Sussex's men to produce a play. The number of boys throughout the period is uncertain. By 1594 the company had broken to go into the country for what would seem to be the last time. After that date we no longer hear of it in London. ${ }^{7}$

Whether The Old Wives Tale was presented in a London theatre, at court, or in the country, perhaps in a private home, whether by the full or divided company, with or without hirelings to round out the complement of players, we do not know. It is not impossible that the play was adapted to all of these circumstances, although a company in financial difficulty might have been reluctant to commit itself to additional salaries. The play has been dated from as early as 1589 to as late as 1593 , and, although it is hotly disputed, some argue that the surviving text is a shortened version of a longer play. ${ }^{9}$ Others feel that, the title page notwithstanding, the play was originally written for a boys' company (where many more actors would have been available) and subsequently acquired by the Queen's Men. ${ }^{10}$

Not only don't we know how many players would have been available for a sixteenth-century production of The Old Wives Tale, but critics cannot agree on the minimum number that would have been necessary to do justice to the play. Frank Hook has summarized a number of assessments ranging from six men and one boy to a minimum of five boys plus an unspecified number of men. ${ }^{11}$ One thing is clear : the number one comes up with depends on the assumptions one makes. Would men on nccasion have played women's roles, as Ringler proposes ? Might boys have taken such men's roles as Jack and the Clown ? ${ }^{12}$ And must Madge, Frolic and Fantastic, whom the text tells us are present through the entire tale, 
always be present in the same role?

It is perhaps useful to remind ourselves that The Old Wives Tale is part of a recognizable stage tradition in which extensive doubling was the norm. Although few examples of the popular genre of dramatic romance survive, one which does also bears a title page ascription to the Queen's Men who perhaps revived it, since although the quarto dates from 1599, it is usually placed in the 1570's. ${ }^{13}$ The anonymous Clyomen and Clamydes has thirty-seven speaking roles plus drum and trumpets and, as a stage direction says, «as many souldiers as can». David Bevington concludes, on the basis of internal evidence and by analogy with other popular plays, that it calls for a company of ten players, three of them boys. ${ }^{14}$ Similarly, of the romance Common Conditions we are told on the title page that «Six may play the comedie» which contains twenty-four roles. ${ }^{15}$

Peele's play is decidedly more sophisticated than these earlier romances, because the narrator of the marvellous adventures and her listeners are interposed between the play and its theatre audience with the result that it «supplie [s] a looking glass or mirror for actual performance» and allows the play to comment on itself. ${ }^{16}$ The fact that roles are doubled - that characters within the tale are transformed into other characters, and the added possibility that the tale's «audience» in the framing induction themselves become characters in the story, can be an illustration of the transforming power of art which the play expresses.

The Old Wives Tale explores the transformations that art can effect. ${ }^{17}$ In Madge's tale the heads in the well can bring prosperity to the poor Celanta and Corebus. The ghost of Jack can fill empty purses, confound the conjurer, and lead Eumenides to his Lady. The black magic of Sacrapant can turn young into old, sane into mad, free into slave, and make Delia forget herself. Similarly the narrative art of Madge can make an audience forget themselves. Just as Sir Philip Sidney recognized 
that poetry could draw old men from the fire and children from play, Frolic tells Madge, «I have seen the day, when I was a little one, you might have drawn me a mile after you with such discourse.» (91-93) ${ }^{18}$. Imagination and words which can transform Clunch's lantern into «a glow-worm, a candle, or a cat's eye,» (31) can also transform their listeners and their speaker.

That the ultrammelled imagination can create its own reality is illustrated by Madge's tale. Madge's imagination is a storehouse of motifs which come from folklore and romance :

One upon a time there was a king or a lord or a duke that had a fair daughter, the fairest that ever was ; as white as snow and as red as blood; and once upon a time his daughter was stolen away, and he sent all his men to seek out his daughter. (113-117).

Her imagination is inclusive. It embraces all the possibilities, even making the sorcerer female as well as male : «She (he, I would say)» (128-129). It is also cumulative rather than consecutive, circling back to pick up narrative elements dropped along the way : «O Lord, I quite forgot! There was a conjurer .... O, I forget ! [He] turned a proper young man to a bear in the night and a man in the day». (128-130).

The consciousness that would order these elements into a coherent narrative is reductive. It expects the father of the fair daughter to be either a king or alord or a duke. It expects that the story will comply with the listener's experienced sense of reality. But when Frolic imposes the physiological imperative that man must eat and the social imperative that a king requires servants on Madge's tale with the question, «Who dressed his dinner, then ?» (119), her reply invites him to choose between the firmament and the fundament : «Nay, either hear my tale, or kiss my tail». (120). The logic of the anal compulsive can cut him off from the creative imagination. 
To listen to the tale is to let the tale exercise its own authority. To tell it is to let it tell itself. As Madge tells her story, it escapes from her conscious control. Not without surprise, nor without resistance. «Gods me bones! Who comes here ?» she exclaims (132). But the story can be a source of discovery. "Let them alone; let us hear what they will say», demurs Fantastic (135). Gradually, Madge begins to enjoy not having to control her narrative, and by the time Huanebango and Corebus enter it is she who replies to Fantastic's «Gammer, what is he ?»with «O, this is one that is going to the conjurer. Let him alone; hear what he says.» (265-267).

Madge's story, the story that comes to life, is a fantasy in which characters who embody charity, reason, love and beauty are released from the enchantments of oppression, unreason and poverty. Also, because «a merry winter's tale [can] drive away the time trimly $\gg(85-86)$,it releases its listeners from the tyranny of the everyday. Clunch's lantern and Madge's hearth dispel the terrors of being lost in the night-time forest. Similarly, Madge's tale helps one to forget (and resolve?) the anxieties of existence. ${ }^{19}$ In the story the metaphorical can become actual and the teller/listeners and their lives can become transformed.

The Old Wives Tale prepares its theatre audience for these transformations early in the play. Even within the induction the traditional boundaries between the imaginary and the «real» are presented as fluid and shifting.

Specific lines addressed to the audience also break the dramatic illusion and include them in the world of the play. When Madge welcomes her guests with cheese and home-made pudding, Antic's comment, «a good example for the wives of our town $»(63-64)$, invites the women in the audience to learn from her. Furthermore if, as Patricia Binnie has suggested, The Old Wives Tale was indeed written and presented as a marriage entertainment, ${ }^{20}$ Fantastic's otherwise confusing line, «Why 
makes thou it so strange, seeing Cupid hath led our young master to the fair lady, and she is the only saint that he hath sworn to serve ?» (11-13), would have been indulgently received by its original audience as a compliment to the guests of honour. ${ }^{21}$ I also argue later that Madge steps out of the frame at the end of the play to address the audience directly.

In The Old Wives Tale the actors and audience, teller and listeners, are repeatedly changing places. The McGill University production, from which I take the following examples, encouraged a redefinition of the audience as protagonists in the play who are themselves transformed. A roughly. square area with the audience of about one hundred fifty spectators on the two downstage sides constituted the stage (Figure 1). The smallness of the theatre generated an intimacy which we tried to make use of.

The Old Wives Tale opens with actors playing pages whose names suggest that they are actors. ${ }^{22}$ In fact Frolic uses histrionics to express his discouragement at being lost in the woods. He quotes (incorrectly) from Terence's Adelphoe, ${ }^{23}$ presumably doing so as an actor putting on a show for his fellow actors who within the play become his audience. If, as well they might, they show their appreciation by applause, Frolic could bow to thank them and include as well the audience in the theatre. Similarly, the possibility exists for miming the three merry men of their song, where they can invite the audience to share the energy of their merriment. Finally, in a small theatre the barking of the dog in the wood and Clunch's entrance could come from the direction of the audience, defined to share the same imaginative space.

For example, the play begins in darkness that affects the characters very strongly. The terrors of being lost «among the owlets and hobgoblins of the forest» (43) leave Frolic 《all amort» and «dead slain» $(1,8)$. This darkness is dispelled with the entry of Clunch, the Smith "with a lantern and candle», according to the stage 


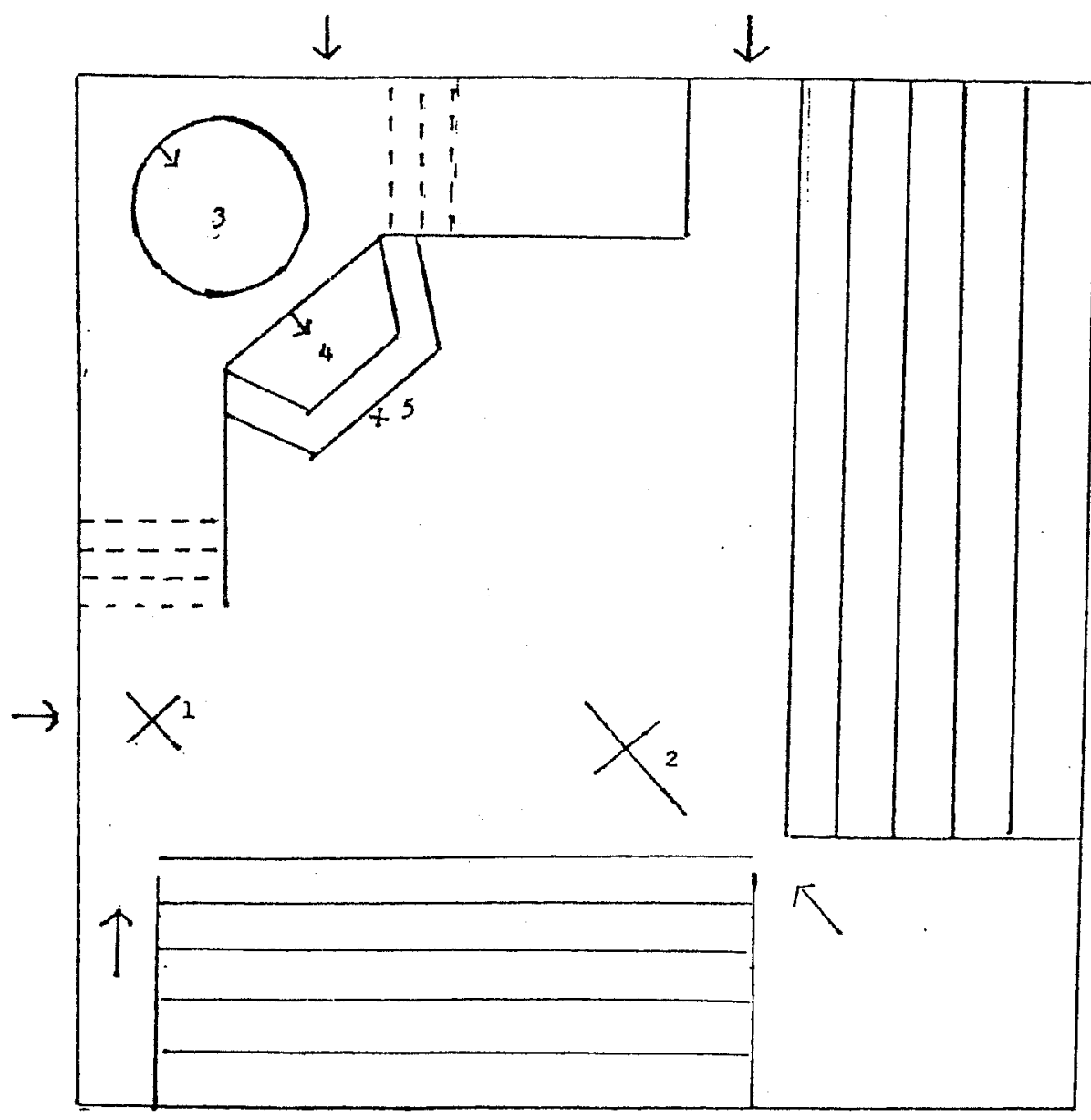

1. Madge's Hearth

2. Erestus' Crossroads

3. Sacrapant's Cell

4. The Well of Life

5. Sacrapant's Light

Figure 1. Set Design for The Old Wives Tale, McGill University, 1981. Designed by Patrick Neilson (Memorial Reconstruction by L. Lieblein) 
direction. (29) On the Elizabethan stage the language, gestures, and lighting instruments (or lack thereof)would have been sufficient to represent the night time. ${ }^{24}$

The McGill University production used artificial lighting, but because the audience surrounded the stage (the front rows effectively were on the stage), it tended to subject the audience to almost the same level of illumination as the stage with which it was continuous. Thus the play opened in near blackness and chaos which was progressively dispelled by Clunch's lantern, Madge's fire, and the brightness which accompanies Madge's tale.

The confusion of the opening scene was meant to be shared by the viewers. The screams of the pages were heard as they ran through the audience and across the playing space. A torch they came in with «accidentally» went out, but not before the figure of Erestus in his form of a bear from whom they were fleeing was seen hovering and lurking near the small low platform which was to mark his downstage crossroads. The dialogue began when the pages found each other in the dimness and reached out to the audience in the ways already described.

The frame of the play then not only contains the story Madge is about to tell, but can help to make the audience watching it part of the dramatic activity they are witnessing. Thus the play's induction transforms the «reality» of the audience by making them, like the characters themselves, present in the woods and at Madge's hearth. In other words, the spectators are transformed by the play just as Madge and her listeners will be by her old wives' tale.

If the discontinuities - the fits and starts and turnings - of the tale itself have the quality of a dream, they also have the anxiety-testing and wish-fulfilling logic of a dream. Madge's story and Peele's play illustrate the twonsformations effected by narrative and dramatic art as well as by dreamwork. Through the doubling of roles in the staging of the play the audience is inviled to witness and experience these transformations. 
The grammar of the transformations is present in the induction. According to Fantastic, "This smith leads a life as merry as a king with Madge his wife» (72-73). The royal is implicit in the rural, waiting to be released. Even in the forest the smith is addressed as «Good Vulcan» (43). Vulcan, of course, is the god of smiths, and Clunch's name suggests Vulcan's lameness. Vulcan was also the husband of Venus, who cuckolded him with Mars.

To have the same player then portray both Madge and Delia is not only economical but is to follow the logic of fairy tale and dream. The Old Wife reappears as the Fair Daughter and is no longer wooed by the lumpish Clunch who must ply his work but by the wandering knight Eumenides, or, more precisely, a Clunch who has become Eumenides.

In order for doubling of this kind to work an actor must be convincing in each role yet recognizable in all of them. In The Old Wives Tale, because Madge and the pages are an audience who mediate between the characters in the tale and the spectators in the theatre, they are able to express for us our skepticism and surprise, and when they are mollified, our doubts too are assuaged.

To give an example, in the McGill production, largely for reasons of economy, the actor playing Clunch doubled as Lampriscus as well as Eumenides. ${ }^{25}$ The entrance of Lampriscus is preceded by the absorbing stage business in which Venelia «Runs madding all enraged about the woods》 (203). Though attentive to the activity of Venelia, Madge started from her seat in recognition of her husband when he entered, but reconciled herself to the primacy of the tale's «reality» over her own when Erestus said, «But here comes Lampriscus, my discontented neighbour» (205-206):In the face of Frolic's astonishment after the Lampriscus scene that the tale has a life of its own («Why, this goes round without a fiddling stick»-253), Madge resumed some authority over her tale by explaining the characters, but her comments suggested her subservience to the conventions of her tale. Thus she described 
Lampriscus as a beggar who dwells upon a green, even though it is irrelevant to his role in the play, and of the Harvest-men who enter she speculates that they will sing a song of mowing.(In fact they sing a song of sowing).

Antic too, it is assumed by most critics, goes off to bed with Clunch in order to reappear in another role. The boyish exuberance of the page who cheers his disheartened friend, initiates the song, makes bawdy replies to Clunch, and invites Madge to tell a tale, reappeared in our production as an animateur himself who turns «sadness》 to joy, the spirit Jack who is «a neat, handsome, and cleanly young lad, about the age of fifteen or sixteen years» (732-733). He was recognized by Frolic who in gesture alerted Fantastic to the fact, but though they tried to get Antic's attention by waving to him, as Jack he did not recognize them.

It is not that the presence of Madge, Frolic and Fantastic need be ignored by the characters of the tale, but that the tale in its telling dominates and subsumes them. Thus in our production they were claimed by the Harvesters for their dance and by Sacrapant as his Furies. The Harvest-men, as many critics have pointed out, are thematically important but dramatically irrelevant. They are central to the play but not necessary to the exposition and untangling of the plot. In our version of Madge's dreamlike tale in which the characters come to life and are transformed, the Harvesters were played by actors of other roles in whatever costumes they happened to be wearing at the moment. They were led dancing in by a fiddler and singer to the strains of their song. Madge and the pages began to clap and sing to the beat, and were quickly invited to join in. Still humming, they resumed their places on stage at the end of the dance and were there to discuss the subsequent entrance of Huanebango an: Corebus. At the second appearance of the Harvesters they sprang up delightedly to join in without waiting to be invited. Frolic and Fantastic were also surprised into action, but this time with reluctance, by Sacrapant the 
Conjurer when he needed two Furies to carry the body of the stunned Huanebango.

Thus the members of the framing induction can move in and out of the tale that comes to life. They are transformed and their lives are enriched by the tale. In their new identities they can experience both frustration and fulfillment.

Other characters within the tale can be doubled as well to underscore themes which the play develops ${ }^{26}$ in order to achieve what Alan Dessen calls linked analogues, «linkages for the eye [which] help to clarify the dramatist's essential point for the viewer in the theatre». ${ }^{27}$ Casting need not be as arbitrary as Harold Jenkins implies in his argument that the text of The Old Wives Tale as it survives represents an abridgement for a reduced company :

So long as they did not appear in the grand finale, Huanebango and Zantyppa or Celanta could be doubled with Erestus and Venelia, or Celanta might even be doubled with Delia; while the actor of Lampriscus could obviously also take the part of Jack, or even Eumenides who, considering that he is more or less the hero of the fairy story, makes a surprisingly late apprearance. ${ }^{28}$

As I have tried to show, the distribution of parts need not be quite so random and benefits from a more careful design. For example, doubling the questing pairs so that the same actors play both Delia's brothers Calypha and Thelea as well as the braggart Huanebango and his clownish servant Corebus underscores the essential symmetry of the inner tale and contrasts the vanity of Huanebango with the humility of the true seekers. ${ }^{29:}$ In fact in our production the only figure who was not doubled was Sacrapant. Although as a sorcerer he is at the heart of many transformations of which the tale speaks and he himself is an old man garbed in the stolen youth of Erestus, his conjurings are destructive, depriving others of their love, their memories, their very identities. 
In contrast, the tranformations of art and dream are benign. If anything, they extend experience and to the extent that they do speak of growth and fulfillment. ${ }^{30}$ (For a complete list of parts as doubled in the McGill production, see Figure 2.)

The versatility of players in multiple roles is a source of pleasure for both actors and audience. Quick changes can be both interpretatively significant and fun in themselves. At the same time we know from the Revels Office documents in the reign of Elizabeth that splendor of costume was much valued in performances at court and undoubtedly, though to a lesser extent, in the theatres as well. ${ }^{31}$

The doubling scheme employed at McGill involved a number of quick changes. For example, blind Corebus exited at line 592 and re-entered as the Second Brother at line 613 . Erestus left the stage at line 468 and returned as the Churchwarden after only five lines. The most stunning shift occurs at the end of the play when Delia exits at line 955 and on the next line is awakened as Madge by Fantastic. For Ringler such proximity bespeaks the impossibility of doubling the roles of Madge and Delia. In practice, as Booth has recognized, the challenge, if met, can produce exhilarating and satisfying results.

Obviously, costumes must be designed to take into account the necessity for lightening changes. In our case we felt that an approximation of Elizabethan dress suited the fairy tale and occasional qualities of the play, but that neither our budget nor the size of the stage and theatre could handle it. Therefore, at the suggestion of our designer ${ }^{32}$ we opted for the expedient of «pieces» (such as hats, ruffs, shoulders, doublets, slops, points, etc.) on a basic costume of leotards and tights to suggest on a smaller scale the Elizabethan silhouette. Thus one could easily exchange the «pieces» and change the character. In a few cases, full length gowns, like those of Erestus and Venelia, could hide other costumes.

In the kind of production I am describing the trans- 


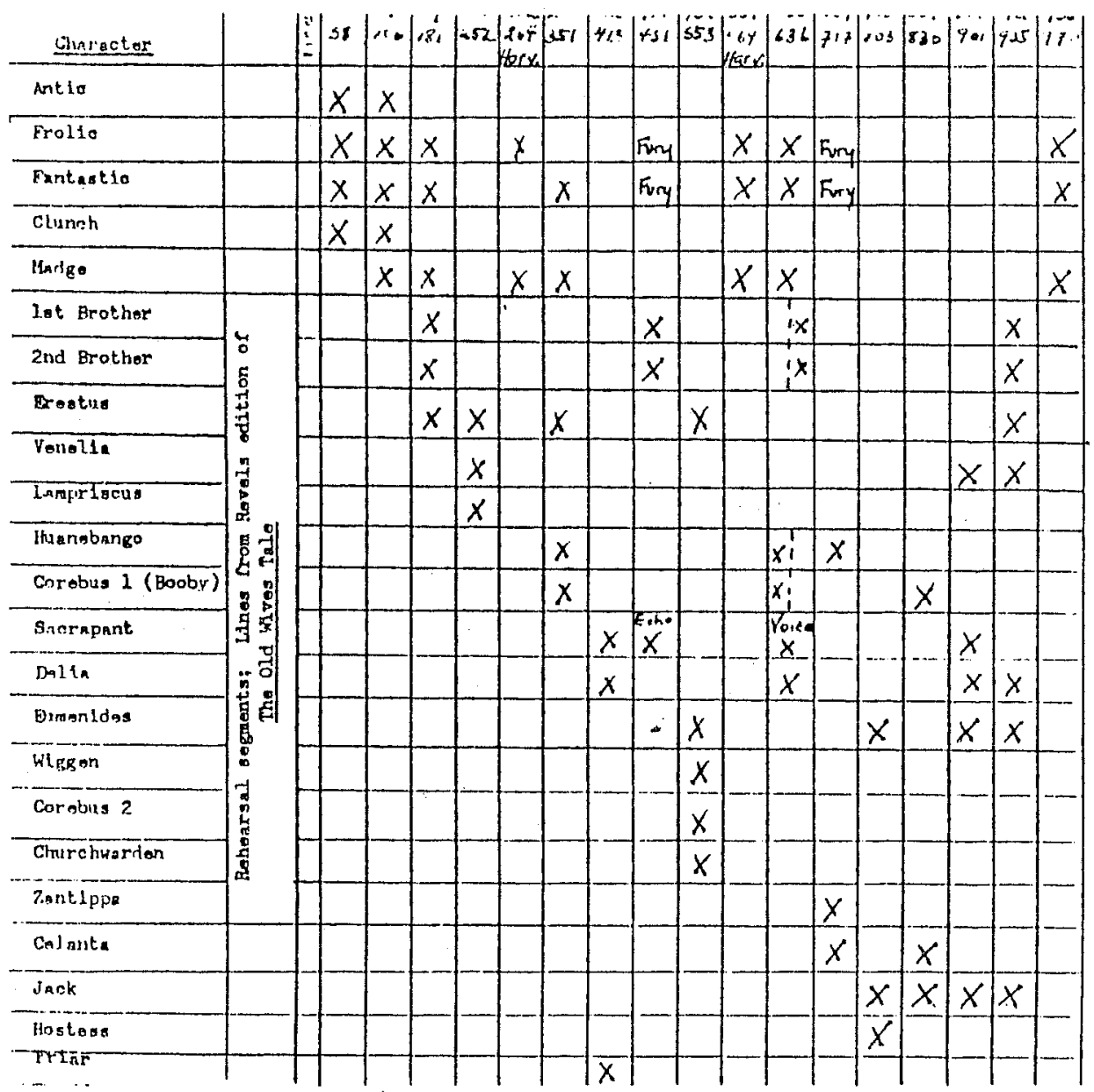

Figure 2. Doubling in The Old Wives Tale, Mc Gill University, 1981.

1. Madge, Delia

2. Clunch, Lampriscus, Eumenides

3. First Brother, Huanebango

4. Second Brother, Corebus 1 (Boody)

5. Erestus, Churchwarden

6. Antic, Ghost of Jack

7. Frolic, Fury

8. Fantastic, Fury

9. Sacrapant (Echo, Voice)

10. Venelia, Friar, Hostess

11. Corebus 2, Zantippa

12. Wiggen, Celanta 
formation of Madge into Delia is critical. The costume of Madge covered that of Delia, and except for the wimple which concealed a head net, was built in one piece, including the padding that bespoke Madge's ample girth. It completely opened at the back so that Delia needed only to slip her arms into the sleeves and have the Velcro pressed together from behind.

At the end of the tale the stage is full, containing Delia and Eumenides, Jack with the head of the Conjurer, Erestus and Venelia, and Delia's two brothers. After Jack leaps into the ground, Eumenides invites them to depart for Thessaly, and all agree : «We follow thee and Delia» (955). The moment lends itself to ceremony, pageantry and music, with bows and recessionals in couples. The tale is joyfully completed, and the theatre audience tends to applaud the satisfying conclusion. But though Madge's tale is done, Peele's Tale is not. In fact there has been just enough time for Delia to reappear as Madge, and like Madge, the audience too is caught napping because, their attention having been elsewhere, many of them, even in a pocket-sized theatre, have not noticed the change. (If they have, it has been with appreciation).

Sleep and story recede in the face of day. The tale is returned to the past from whence it came, but with ambiguity : «When this was done, I took a piece of bread and cheese, and came my way» (968-969). Is Madge speaking of herself on other occasions when she similarly told a tale, as Patricia Binnie suggests ? ${ }^{33}$ Or is she, as it seemed in our production, acknowledging herself as Delia within the tale? What else would a king's daughter do after she had narrowly missed being cut in half ? Surely not leave for Thessaly'without breakfast. The elements of romance which have, in her tale, imaginatively transformed Madge into a princess and Clunch into a wandering knight are transformed in turn by the exigencies of rural life. "And so shall you have too, before you go, to your breakfast», she concludes (969-970). Is she merely repeating herself ? She has already said to Fantastic and 
Frolic, «But, come, let us in. We will have a cup of ale and toast this morning - and so depart» (963-965) $\mathrm{S}$. Musgrove, in an otherwise highly speculative argument that The Old Wives Tale was written as an afterpiece, makes the interesting suggestion that the play proper ends when Madge replies «Yes, faith» (968) to Fantastic's query : "Then you have made an end of your tale, gammer ?» (966-967) ${ }^{34}$. The last three lines, «When this was done ... And so shall you have too ...», are addressed to the audience, who themselves have been transformed by the play into guests of Madge.

LEANORE LIEBLEIN

NOTES

1. William A Ringler, Jr., "The Number of Actors in Shakespeare's Early Plays," The Seventeenth-Century Stage, ed. Gerald Eades Bentley (Chicago : University of Chicago Press, 1968), pp. 110-134; Stephen Booth, "Speculations on Doubling in Shakespeare's Plays», Shakespeare: The Theatrical Dimension, ed. P.C. Mc. Guire and D.A. Samuelson (New York : AMS Press, 1979), pp. 103-131.Booth,p. 128, summarizes previous studies.

2. Ringler, p. 127 .

3. David M. Bevington, From 'Mankind'to Marlowe (Cambridge, Mass.: Havard University Press, 1962), pp. 86-98.

4. Booth, pp. 127, 108,114.

5. Theatre Laboratory, McGill University, Montreal, Canada. I am deeply indebted to co-director Anthony Paré for his ideas, experience and support.

6. For a review of the literature see John Doebler, "The Tone of George Peele's The Old Wives' Tale», English Studies, 5 3(1972), 413,418. Harold Jenkins, "Peele's The Old Wives' Tale», Modern Language Review, 34(1939), 177-185, cites Greg's views that the quarto offers a «mutilated text» and argues for an abridgement. S. Musgrove, «Peele's Old Wives Tale : An Afterpiece?» 
Du Texte à la Scène : Langages du Théâtre.

AUMLA, Journal of the Australasian Universities Language and Literature Association, 23(1965), 86-95, and Patricia Binnie, ed., The Old Wives Tale, The Revels Plays (Manchester and Baltimore: Manchester University Press and The Johns Hopkins University Press, 1980), pp. 12-20, argue that the play survives as written, possibly for private performance.

7. E.K. Chambers, The Elizabethan Stage, 4 vols. (Oxford: The Clarendon Press, 1923), 2:104-115.

8. W.W. Greg, Two Elizabethan Stage Abridgements, (Oxford: The Clarendon Press, 1923), p. 127; F.S. Hook, ed, The Old Wives Tale, The Dramatic Works of George Peele, Vol. III (New Haven and London : Yale University Press, 1970), pp. 306-311. Binnie, pp. $5-6$.

9. Hook, pp. 354-372, and Binnie, pp, 12-20, offer the most systematic refutations of the argument for abridgement.

10. Hook, p. 372. Binnie, p. 34, cites two modern directors of the play who have expressed the same surmise.

11. Hook, p. 355 .

12. Ringler, p. $130 ;$ Hook, p. 355 .

13. Betty J. Littleton, ed., «Clyomon and Clamydes》: A Critical Edition (The Hague and Paris : Mouton, 1968), pp. 30-33.

14. Bevington, p. 194.

15. Ibid. Tucker Brooke, ed. Common Conditions, Elizabethan Club Reprints, No 1 (New Haven : Yale University Press, 1915), pp, 59-60, proposes a doubling scheme similar to that suggested by Bevington. Greg, pp. 119-122, argues that another play by Peele, The Battle of Alcazar, survives in a corrupt version because of the need to reduce the number of actors.

16. M.C. Bradbrook, «Peele's Old Wives'Tale : A Play of Enchantment», English Studies, 43(1962), 328. Jackson Cope, The Theater and the Dream: From Metaphor to Form in Renaissance Drama (Baltimore and London : Johns Hopkins University Press, 1973), passim, develops the importance of the self-reflexive play as a Renaissance genre.

17. Susan T, Viguers, "The Hearth and the Cell : Art in The Old Wives Tale», Studies in English Literature, 21(1981), 209-221. Ms. Viguers, with whom l largely agree, also derives her views from the experience of directing the play, though on a reb igular stage, presumably with the audience in front. She nowhere addresses the possibility of doubling.

18. All quotations from The Old Wives Tale come from the Revels edition, ed. Patricia Binnie, and will hereinafter be documented in parentheses in the text. 
19. Bruno Bettelheim, The Uses of Enchantment: The Meaning and Importance of Fairy Tales (London : Thames and Hudson, 1976), p assim.

20. Binnie, p. 38 .

21. The line also suggests that out of the unknown and unseeing - the darkness of which Frolic is complaining and the blindness of Cupid - can come light and love and loy alty.

22. Bradbrook, p. 324 .

23. Binnie, p. 37 .

24. See reference to articles by Alan/Dessen and R.B. Graves in Michael Shapiro, «Annotated Bibliography on Original Staging in Elizabethan Plays, $R$ esearch Opportunities in Renaissance Drama, 24(1981), 38.

25. Lampriscus has in common with Clunch his homespun simplicity. He differs from Clunch's stolidity, however, in his exuberant language. Furthermore, the disharmony of his two marriages is in direct contrast to the apparent domestic felicity of Clunch and Madge.

26. Viguers, op. cit.; Binnie, p. 14, and John D. Cox, "Homely Matter and Multiple Plots in Peele's Old Wives Tale», Texas Studies in Language and Literature, 20(1978), $334 \mathrm{ff}$. , stress the themes of hospitality and fertility.

27. Alan C. Dessen, Elizabethan Drama and the Viewer's Eye (Chapel Hill : University of North Carolina Press, 1977 ), p. 51.

28. Jenkins, p. 184 .

29. Cox, p. 359, emphasizes the contrast between Huanebango and Eumenides. I would argue that the same relationship applies between Huanebango and Delia's brothers.

30. Another proposal for doubling some of the roles occurs in The Old Wife's Tale, New Vampt and Adorned with Figures (London : Sidgwick and Jackson, 1911). W.W. Greg (whosename appears in the British Museum catalogue entry but not on the title page), on the assumption that \&there is little doubt that what we possess is no more than a mangled carcass》, attempts «to refashion out of the remains something like a plausible whole» (p.3). While, with Hook and Binnie, $I$ do not agree that the text is necessarily truncated and therefore find the shifting about of scenes unnecessary, the addition of lines heavy-handed, and the embracing of the premisses of the picture frame stage anachronistic, I find consistent with $m y$ own argument the suggestion that Madge's cottage is transformed into the in while Madge becomes 
the Hostess and Fantastic the Fiddler. Similariy, Frolic moves into the tale to become Jack and subsequently, keeping his whitened face, returns to his former costume and character. Fantastic (and here it is less clear why) also steps out of the frame to play the role of Wiggen, which is combined with that of Corebus, and returns to Madge, who has noted his absence, with «Say, played I not my part well ?" (p. 39). I am indebted to Patricia Binnie for this reference.

31. Morton Paterson, «The Stagecraft of the Revels Office During the Reign of Elizabeth as Suggested by Docu. ments Relating to the Office", Studies in the Elizabethan Theatre, ed. Charles T. Prouty (Hamden, Connecticut : The Shoestring Press, 1961), pp. 1-52.

32. Costumes were designed by Pamela Lampkin.

33. Binnie,p. 92 .

34. Musgrove,p. 94 . 